\title{
Cardiogenic shock in Non-ST elevated AMI patients in a rural tertiary care hospital in Eastern India
}

\author{
Pal S. K. ${ }^{1}$, Sarkar D. ${ }^{2}$, Sarkar L. ${ }^{3}$, Bandyopadhyay R. ${ }^{4}$ \\ ${ }^{1}$ Dr. Shyamal Kanti Pal, RMO cum Clinical Tutor, ${ }^{2}$ Dr. Debasis Sarkar. Assistant Professor, ${ }^{3}$ Dr. Liton Sarkar. \\ RMO-Cum-Clinical Tutor. ${ }^{4}$ Dr. Ramtanu Bandyopadhyay. Professor, all authors are affiliated with Department \\ of Medicine, Malda Medical College, Malda,West Bengal, India
}

Corresponding Author: Dr. Debasis Sarkar, Assistant Professor, Department of Medicine, Malda Medical College, Malda, WB, India, Email: dr.debasis99bmc@yahoo.in

\begin{abstract}
Introduction: Acute Myocardial infarction is one of the leading causes of morbidity and mortality worldwide. Cardiogenic Shock is the leading cause of death in patients hospitalised for acute MI. Although there is substantial evidence for a benefit of reperfusion therapy for ST elevation MI, the best treatment strategy for patients with non-ST segment elevated MI is less well defined. Outcome and prognosis differs with the presence or absence of ST segment elevation. Most of the studies have been done on urban population. Objective: To determine the frequency and profile of Non-ST elevated MI. Any differences in profile in a Rural population with different social and economic structure will also be documented. Methods: In this descriptive crosssectional study conducted in Medicine department, Malda Medical College \&Hospital,WestBengal,India 100 patients of non STEMI are selected by using consecutive non probability sampling technique. After taking ethical clearance from Institution and consent from patients and their relatives, 100 patients of non STEMI are enrolled as per inclusion and exclusion criteria. They are evaluated for cardiogenic shock on the basis standard clinical examination and are managed as per protocol. All relevant data are recorded in predesigned proforma. Results: Out of 100 patients, 68 are male and 32 are female. Mean age of the patients is $60+1.26$ years and majority of them are in the age group of $61-70$ years(41\%). $5 \%$ patients of non STEMI developed cardiogenic shock and majorities are male and more than $50 \%$ of patients with cardiogenic shock with non STEMI are above 70 years old. Conclusion: Frequency and Profile is comparable to other studies. This rising trendin a rural population of a developing country is due to probably more urbanisationrelated to change in food habits and life style changes.
\end{abstract}

Key words: Cardiogenic shock (CS), non-ST elevated AMI, ST-elevated AMI, Myocardial infarction

\section{Introduction}

Coronary artery disease is one of the leading causes of death in globally. Risk of developing coronary artery disease is gradually rising in developing countries apart from developed countries. This is attributed to changes in food habits, life style changes and decreased physical activities. Smoking and alcohol has added additional risk to the problem. Most importantly it is noted that incidence of coronary artery disease in south east Asian is more among younger population (52.5 + 10.8 years) than western countries[1]. Though

Manuscript received: $30^{\text {th }}$ November 2017

Reviewed: $9^{\text {th }}$ December 2017

Author Corrected: $18^{\text {th }}$ December 2017

Accepted for Publication: 22 ${ }^{\text {nd }}$ December 2017 robust studies are available on ST elevated MI and mostly in urban population, there are little study to obtain the comprehensive data on characterisation of non ST elevated Myocardial infarction and that too in a rural population. However depending on available researches, the fraction of patients having non-ST elevation AMI is around $16.5 \%$ of the patients of ACS [2]. Cardiogenic shock, a deadly complication of AMI, is characterised by poor end organ perfusion due to malfunction of cardiac contractility[3]. It is commonly seen in ST segment elevated AMI. But it is found that cardiogenic shock can occur in high risk patients having non ST elevated AMI in about $2.5 \%$ of cases. Cardiogenic 
shock needs early identification, timely aggressive treatment with invasive strategy using coronary angiogram and angioplasty [4]. Compared with ST elevated AMI, patients of non ST elevated AMI are older and have more cardiac risk factors or co morbidities like diabetes, hypertension, dyslipidaemia. Cardiogenic shock in non-ST elevated AMI is less identified early and treated less aggressively due to misconception with Nontransmural MI, risk of death is more compared to ST elevated AMI[5].

Objective:1. To determine the frequency of cardiogenic shock in patients of non ST elevated AMI in a rural population. 2. To compare any differences in a rural population with different social and economic structure.

\section{Methods}

a) Study Type: Descriptive cross-sectional study. b) Sample size: Total of 100 patients of non ST elevated AMI were enrolled.

c) Sampling technique: Consecutive non probability sampling technique used. d) Inclusion criteria: Patients aged 18 years and above of both the sexes admitted through the outpatient department or emergency having non ST elevated AMI.

e) Exclusion criteria: Renal compromised patients, advanced heart failure patients, patients with pericarditis.

f) Procedure: After taking approval from hospital ethical committee, a written informed consent were taken from patients of non ST elevated AMIand their relatives explaining the purpose and benefits of the study. Patients were selected on the basis of characteristic chest pain, electrocardiographic ST depression of $>0.5 \mathrm{~mm}$. in contagious leads, elevated serum troponin- $\mathrm{T}$ of $>0.1 \mathrm{ng} / \mathrm{dl}$ admitted in general medicine ICCU. A detailed history was taken followed by complete clinical examination and all investigations were done. They were looked for signs and symptom of low perfusion pressure for detection of cardiogenic shock. Frequency of cardiogenic shock were noted among the patients of non ST elevated AMI according to sex composition, age group and proper management were given in wards /CCU as per protocol.

\section{Results}

Out of 100 patients of non ST elevated AMI 68 were male and 32 were female. Regarding age distribution of 100 study patients, 4 patients were in 41-50 years age group, 22 patients from 51-60 years age group, 39 patients from 61-70 years age group and 35 patients were from 71 years and above age group. Mean age of study patients was $60+1.26$ years. Overall 5 patients with non ST elevated AMI developed cardiogenic shock whereas 95 patients did not have cardiogenic shock. Among 5 patients of cardiogenic shock with non ST elevated AMI 3 were male and 2 were female and half of them were above 70 years old. 3 patients out of 5 patients with cardiogenic shock are in the age group of above 70 years, 1 patient with cardiogenic shock lies in the age group of 61-70 years and 1 patient with cardiogenic shock lies in the age group of 51-60 years.

Table-1 showed that there was no significant difference in association of gender and age group distribution with cardiogenic shock in patients with non ST elevated AMI.

Table-1: Association of Gender, age distribution of AMI WITH Cardiogenic Shockin patients with Non ST Elevated AMI.

\begin{tabular}{|c|c|c|c|c|c|c|}
\hline \multicolumn{2}{|c|}{ Characteristics } & \multicolumn{3}{|c|}{ Cardiogenic Shock } & \multirow{3}{*}{$\begin{array}{c}\text { Total } \\
(n=100)\end{array}$} & \multirow{3}{*}{$\begin{array}{l}\mathrm{P} \text { value (Chi } \\
\text { Square test) }\end{array}$} \\
\hline & & \multirow{2}{*}{$\begin{array}{c}\text { Yes } \\
\begin{array}{c}\text { Frequency } \\
(n=5)\end{array}\end{array}$} & \multicolumn{2}{|c|}{ No } & & \\
\hline & & & $\begin{array}{c}\text { Frequency } \\
(\mathrm{n}=95)\end{array}$ & Percent-age & & \\
\hline \multirow{2}{*}{$\begin{array}{c}\text { Gender } \\
\text { distribution }\end{array}$} & Male & 3 & 65 & $68.4 \%$ & 68 & \multirow[b]{2}{*}{0.27} \\
\hline & Female & 2 & 30 & $31.6 \%$ & 32 & \\
\hline \multirow{4}{*}{$\begin{array}{c}\text { Age } \\
\text { distribution } \\
\text { (years) }\end{array}$} & $40-50$ & 0 & 4 & $4.2 \%$ & 4 & \multirow{4}{*}{0.21} \\
\hline & $51-60$ & 1 & 21 & $22 \%$ & 22 & \\
\hline & $61-70$ & 1 & 38 & $40 \%$ & 39 & \\
\hline & $>70$ years & 3 & 32 & $33.8 \%$ & 35 & \\
\hline
\end{tabular}


Original Research Article

\section{Discussion}

Coronary artery disease is very common in developed countries, affecting the majority of adult person over the age of 60 years but this problem is rising in rural populations of developing countries, affecting agegroup comparable to that of developed countries.Left ventricular dysfunction (LVD) is the most frequent cause of cardiogenic shock [13]. In a recent trial, it was highlighted that LVD was the main etiology[14] occurring in $74.5 \%$ of patients. This was followed by acute mitral regurgitation $(8.3 \%)$, ventricular septal rupture $(4.6 \%)$, isolated right ventricular shock $(3.4 \%)$, tamponade or cardiac rupture $(1.7 \%)$, and other causes $(8 \%)$.

Mean age of this study is $60+1.26$ years as compared to $62+5$ yearsin COURAGE trial conducted in USA [5]. In this study most of the The relative importance of coronary artery disease varies across regions and from country to country. The patients are in the age group 61-70 years $(39 \%)$ followed by above 70 years $(35 \%)$. $68 \%$ of patients in this study are male and $32 \%$ of patients are female and these findings are similar to study conducted by Saleheen D et al[6]. From this study it is found that cardiogenic shock is present in $5 \%$ of patients of non ST elevated AMI and almost all of them are above 50 years of age.

Similar results are found in a study done by Rosamond W et al [7] in which cardiogenic shock is present in non ST elevated AMI in about 6\% and most of them are above 50 years old.In another study by $\mathrm{R}$ Bhardwaj in 2014, incidence of NSTEMI in young adults ( $<40$ years of age) was found to be $5.84 \%$ [15]. However, Holmes DR jr, et al [8] and Jacobs AK, et al [9] reported cardiogenic shock is present in $2.5 \%$ of patients of non ST elevated AMI. Frequency of cardiogenic shock in STEMI is 7.5\% [10,11]. According to Jacobs AK et al,patients of non ST elevated AMI with cardiogenic shock have a greater risk profile than STEMI with cardiogenic shock though there is no difference in in-hospital mortality[9].

There is a clear male preponderance $(68 \%)$ of affection of non ST elevated AMI in this study. Male preponderance affection of non ST elevated AMI with or without cardiogenic shock is also observed in a study done by Polonsk L et al [12] and Reynold et al [4].

\section{Conclusion}

Life threatening Cardiogenic shock occurs in 5\% of patients with non ST elevated AMI. It is present more among in 61-70 years age group of people and more in male patients. Cardiogenic shock in non ST elevated AMI is relatively more common in our set up than internationally reported.

It is evident from this study that cardiogenic shock is not uncommon in Non-STEMI patients even in rural areas of this part of India. It is often undiagnosed and underreported in literature. Management of this condition should be done with equal emphasis to prevent mortality from potentially treatable condition.

\section{Contribution by authors}

SK Pal: Concept Design and Conducted the study and writing the manuscript.

D Sarkar: Conducted the study and writing the manuscript.

L Sarkar: Result analysis and statistical methods.

R Bandyopadhyay: Guiding the study procedure and preparing the manuscript for suitability for publication.

\section{Funding: Nil, Conflict of interest: None Permission of IRB: Yes}

\section{References}

1. Teoh M, Lalondrelle S, Roughton M, Gro-cottMason R, Dubrey SW. ACS and its presentation in Asian Caucasian patients in Britain. Heart 2007; 93: 183-8.

2. Rosamond W, Flegal K, Friday G, FurieK, Go A, GreenlundK, et al. Heart disease and stroke statistics-2007 update: A report from the American heart association statisticcommittee and stroke statistics subcommittee. Circulation 2007: 115.115 (5): e69-171.

3. Jafary MH, Samad A, IshaqM, Vohra EA. Profile of acute myocardial infarction(AMI) in Pakistan. Pak J Med Sci 2007; 23(4): 485-9.

4. Reynolds HR, Hochman JS. Cardiogenic shock: current concepts and improving outcomes. Circulation. 2008 Feb 5;117(5):686-97. doi: 10. 1161/CIRCULATIONAHA.106.613596. 
5. Boden WE, O'rourke RA, Teo KK, hartigan PM, Maron DJ, Kostuk W, et al. The evolving pattern of symptomatic coronary artery disease in the United States and Canada: Baseline characteristics of the Clinical Outcomes Utilizing Revascularization and Aggressive Drug Evaluation (COURAGE) trial. Am J Cardiol 2007; 99(2): 208-12.

6. Saleheen D, Zaidi M, Rasheed A, Ahmad U, Hakeem A, Murtaza M, et al. The Pakistan risk of myocardial infraction study: A resource for the study of genetic, lifestyle and other determinants of myocardial infraction in south Asia ,Eur $\mathrm{J}$ Epedemiol 2009; 24(6): 329-38.doi: 10.1007/s 10654-009-9334-y. Epub 2009 Apr 30

7. Rosamond W Flegal K, Furie K, Go A, Greenlund K, Hassan N et al. Heart disease and stroke statistics- 2008 update: a report from the American Heart Association Statistics Committee and Stroke Statistics Subcommittee. Circulation 2008; 117(4): e25-146.

8. Holmes DR Jr, Berger PB, Hochman JS, Granger CB, Thompson TD, Califfic RM, et al. Cardiogenic shock in patient with acute ischemic syndromes with and without ST-segment elevation. Circulation. 1999 Nov 16; 100(20): 2067-73.

9. Jacobs AK, French JK, Col J, Sleeper LA, Slater JN, Carnendran L, et al. Cardiogenic shockwith non-ST-segment elevation myocardial infraction: a report from the SHOCK trial registry. J Am Coll Cardiol. 2000; 36: 1901-96.

10. Goldberg RJ, Gore JM, Alpert JS,Osganian V, de Groot J, Bade J, et al. Cardiogenic shock after acute myocardial infraction. Incidence and
Original Research Article

mortality from a community-wide perspective, 1975 to 1988. N Engl J Med.1991 Oct 17; 325 (16): 1117-22.

11. H olmes DR Jr,Bates ER, Kleiman NS, Sadowski Z, Horgan JH, Morris DC, Califf RM, Berger PB, Topol EJ. Contemporary reperfusion therapy for cardiogenic shock: the GUSTO-I Investigators. Global Utilization of Streptokinase and Tissue Plasminogen Activator for Occluded Coronary Arteries. J Am Coll Cardiol. 1995; 26(3): 668-74.

12. Polonsk L, Gasior M, Gierlotka M, Kalarus Z, Cielinski A, DubialSJet al. Polish registry of acute coronary syndromes (PL-ACS) characteristics, treatments and outcomes of patients with acute coronary syndromes in Poland. Kardiol Pol 2007; 65: 861-72.

13.Hochman JS, Buller CE, Sleeper LA, et al. Cardiogenic shock complicating acute myocardial infarction: etiologies, management and outcome: a report from the SHOCK trial registry. J Am Coll Cardiol. 2000;36:1063-70

14. Hochman JS, Boland J, Sleeper LA, et al. Current spectrum of cardiogenic shock and effect of early revascularisation on mortality. Results of an international registry. SHOCK registry investigators. Circulation. 1995;91:873-81.

15. Bhardwaj R, Kandoria A, Sharma R Myocardial infarction in young adults-risk factors and pattern of coronary artery involvement. Niger Med J. 2014 Jan;55(1):44-7. doi: 10.4103/03001652.128161 .

\section{How to cite this article?}

Pal S. K, Sarkar D, Sarkar L, Bandyopadhyay R. Cardiogenic shock in Non-ST elevated AMI patients in a rural tertiary care hospital in Eastern India. Int J Med Res Rev 2017;5(12):1000-1003.doi:10.17511/ijmrr. 2017.i12.05 